\title{
ResearchArticle
}

\section{Effects of plant growth hormones on shoot proliferation of Musa paradisiaca cv. BANTAL}

\author{
BANDITA DEO AND BIKRAM PRADHAN
}

\section{SUMMARY}

The present experiment was conducted to study the effects of three plant growth hormones BAP, kinetin and IAA for the enhancement of shoot proliferation of Musa paradisiaca, cv. BANTAL. From the in vitro multiplication culture the data analysed on the basis of parameters like percentage of response, days of response, number of shoot buds and number of shoots. Among all BAP with IAA was found to be more effective than kinetin along with IAA. Out of various treatments the optimum concentration for the growth and proliferation of shoot in multiplication phase was found in MS $+4 \mathrm{mg} / \mathrm{l} \mathrm{BAP}+0.5 \mathrm{mg} / \mathrm{l} \mathrm{IAA}$ followed by $2 \mathrm{mg} / \mathrm{l} \mathrm{BAP}$ and $4 \mathrm{mg} / \mathrm{l} \mathrm{kinetin.}$

Key Words : Musa, Plant growth hormones, Bantal

How to cite this article : Deo, Bandita and Pradhan, Bikram (2017). Effects of plant growth hormones on shoot proliferation of Musa paradisiaca cv. BANTAL. Internat. J. Plant Sci., 12 (2): 135-138, DOI: 10.15740/HAS/IJPS/12.2/135-138.

Article chronicle : Received : 14.01.2017; Revised : 28.04.2017; Accepted : 16.05.2017

\section{MEMBERS OF THE RESEARCH FORUM}

\section{Author to be contacted :}

BANDITA DEO, Plant Physiology and Biochemistry Division, Regional

Plant Resource Centre, Nayapalli, BHUBANESWAR (ODISHA) INDIA

Email : bdeo2008@gmail.com

Address of the Co-authors:

BIKRAM PRADHAN, Plant Physiology and Biochemistry Division, Regional Plant Resource Centre, Nayapalli, BHUBANESWAR (ODISHA) INDIA

Email : sudhams99@gmail.com 